\title{
Challenges of State Security through the Lens of ATO/JFO Literature
}

\author{
Anhelika DILAI ${ }^{1}$, Ruslan KOLTSOV ${ }^{2}$ \\ ${ }^{1}$ Scientific and organizational center, Department of military journalism, Military Institute of Taras Shevchenko \\ National University of Kyiv, Address: Lomonosova St., 81, 03022, Kyiv, Ukraine \\ ${ }^{2}$ Faculty of Finance and Law, Department of Geoinformation Systems and Technologies, Military Institute of Taras \\ Shevchenko National University of Kyiv, Address: Lomonosova St., 81, 03022, Kyiv, Ukraine
}

E-mails: ${ }^{1} l i k a \_d i l a y @ u k r . n e t ;{ }^{2}$ virus34@ukr.net

\begin{abstract}
This article highlights the issue of national security through the lens of literature development. Since the information war has been going on against Ukraine for a long time, the instruments of influence on the consciousness of the population are constantly changing and the forms and methods of information dissemination are being improved, we decided to investigate the literary sources created during the Anti-terrorist Operation / Joint Forces Operation (further - ATO/JFO) period in order to highlight the trends of opinion formation. We used content analysis methods as a basis. The analyzed source base confirmed the thesis that fake and post-truth are artificially created and manipulativeimitation technologies that Putinists use for hybrid warfare. By imposing the post-truth era on the international community, the Kremlin regime creates a reality where emotions are dominated by facts. Thus, Russia's information strategy is based solely on the needs of the lower order.
\end{abstract}

KEY WORDS: security, media, literature, hybrid aggression

\section{Introduction}

The almost unconcealed attack by the Putin regime on Ukrainian democracy has caused shock in the West, from which it has not yet fully recovered. One of the evidences of this situation is the statement by the chairman of the most important non-governmental forum on security - Munich Security Conference - V. Ischinger before the opening of this meeting: «2017 will be the year of the highest level of uncertainty for the world» [1].

The traditional Munich Security Report 2017, which is being produced over the year by over twenty of the world's leading security institutes, has been dubbed «Post-Truth,» «Post-Event,» «Post-Order?» This agenda is uniquely inspired by the Kremlin's global influence technologies, one of which is the post-truth issue [2].

Information in today's world plays a key role in all aspects of life, especially security. The media have become a platform for discussion and for terrorism, which today is the publicity. The ultra-fast dynamics of the information space led to the news that it lives the maximum of the day. And naturally, the question is, is there anything that can have a lasting effect and what can we use in the security field?

Such an instrument has been the literature that has raised to the surface the «blind» zones of security institutions, problems and trends of the modern post-information world. Literature as a medium of communication is the most talked-about source for security research, particularly in Ukraine.

The sources of our study were prose for the period 2014-2019, describing the armed aggression of Russia against Ukraine, written by direct participants in hostilities, volunteers, internally displaced persons (real refugees), public figures, journalists, writers. In our research we emphasize on ability of literature to influence to a key audience and force them to act in a different way.

Literature is a part of social communications. Professor Volodymyr Rizun says that social communications are always:

- $\quad$ man-made, artificial, invented by people, specialists, are artifacts;

- technological;

- $\quad$ provide the functioning of ideas, information, views, etc. (socially relevant information) in the form of various documents;

- $\quad$ strategic;

- $\quad$ systemic;

\footnotetext{
${ }^{1}$ Corresponding author.

E-mail address: lika_dilay@ukr.net.
} 
- $\quad$ organized;

- institutionalized and provide for the creation of social and communication

- institutes and availability of professionals;

- public;

- $\quad$ have an activity character, turn communication into a communication and production activity;

- provide the production of ideas, information, views, etc. in the form of various works (information production);

- $\quad$ cannot exist without social memory;

they are held not only on moral and ethical grounds, but also have a legal basis "[15].

We want to emphasize on several thigs that are related to literature as a part of communicative process. There are technological, strategic and public. First, literature has a purpose and always know what the audience is. Literature is always strategic because the idea will live for a long period despite of the news which are important only one day then they become just a fact. That's why when we talk about literature, we have to understand that it is the tool for the strategic communications also to share the narratives to society. The last thing is public. Literature creates public opinion and changes people's behavior. It concludes different ways of influence from sharing data to force acting. Especially media and literature walk around emotional issue that becomes more powerful to change human's lifestyle than weapon. Usually person can be persuaded through emotions of fear or totally relaxation. Nowadays these two spheres become weapon in fight for human's mind.

According to professor O. L. Bilychenko literary communication is a component of the social communication system; literary and critical statements, understood as communicative actions, always become dependent on certain political, economic, social and cultural conditions, which determines their relevance [14]. In this context, the category of communication activity in the artistic sense is one of the most expressive categories, which largely defines society from an informational point of view.

In the process of literary communication, the addressee has three types of relationships: author - reality; author - recipient; the author is an artistic process. Thus, each level of information interaction is characterized by specific concepts of information, different approaches to their scientific description. Information interaction can be seen as a kind of social and communication interaction, which is carried out through the messaging system [14].

In our opinion this is the critical issue because literature can blur the boundaries between official and unofficial information. In this case government monopoly on information couldn't exist anymore. We have to understand that in case of Joint Force Operation in Ukraine there is a possibility to create a huge gap between society as a result of lack of information. This is also challenge for information security by reason of bad internet connection, pro-russian media, weaknesses of technologies etc. That's why we focus on literature as a sustainable feature for counterattack and protection of national security system.

The study revealed a number of problems: lack of diverse information directly in the ATO area, insufficient number of state-owned media, poor external and internal communication, lack of sufficient cultural enrichment of fighters as a way of psychological unloading.

Modern dynamics of the information space have opened up many opportunities for researchers to study the communication system. The international community and each country in particular have faced the problem of total information confrontation. Journalism has indeed become the fourth power, information is the most expensive currency. The war is not about territories, but about the minds of the population. The new era of rapid development of social media has led to the emergence of such concepts as «post-truth» and «fake». Due to this, the main issues of global security systems have become the question of how to protect ourselves and the country in the context of total information confrontation between superpowers and less important players in the political arena.

\section{Methodology}

The main methods are content analysis and critical discourse analysis, which identify problems into the dynamic military-political sphere of Ukraine, where public negative becomes a challenge to strategic communications in the security and defense sector. First, we have to identife and analyze such key concepts as «post-truth» and «hybrid war» as the realities of the new era of «misinformation» and «fake» as tools for achieving the goals of «posttruth» and «hybrid war».

Content analysis is a research method for studying documents and communication artifacts, which might be texts of various formats, pictures, audio or video. Social scientists use content analysis to examine patterns in communication in a replicable and systematic manner. Content analysis is a widely used qualitative research technique. Rather than being a single method, current applications of content analysis show three distinct approaches: conventional, directed, or summative. All three approaches are used to interpret meaning from the content of text 
data and, hence, adhere to the naturalistic paradigm [16].

Critical discourse analysis (CDA) is also used qualitative research technique. These analyses examine the discourse - the social 'story' at play in the investigation - but also ask why that particular person is relating that particular tale. Critical discourse analysis examines the dominant and subordinate discourses on offer in society and explores notions of resistance and appropriation of discourses among various social actors [17].

These two methods are related to each other and help us deeply understand the goal of literature communication in difficult socio-political issue. It helps researchers to find hidden intention of communication and eliminate narratives. Consequently, we use these two methods to study our subject.

Data collecting sources description

\begin{tabular}{|l|l|}
\hline Year & Amount \\
\hline 2014 & 10 \\
\hline 2015 & 78 \\
\hline 2016 & 102 \\
\hline 2017 & 95 \\
\hline 2018 & $81(+3$ reissued $)$ \\
\hline 2019 & 65 \\
\hline \multicolumn{2}{|c|}{ Language } \\
\hline Ukrainian & 312 \\
\hline Russian & 98 \\
\hline \multicolumn{2}{|c|}{ Gender } \\
\hline Male & $70 \%$ \\
\hline Female & $30 \%$ \\
\hline
\end{tabular}

Table 1.

To reach our goal we analyze in total 273 books of prose which were published, among which 85 books were written by military writers, 9 photo albums, 15 comics (graphic stories), 3 books with stories in the form of a play (script), about 27 poetry collections were published (Table 1.).

Male-female and female-authors are in the percentage of somewhere between $70 \% / 30 \%$, including about 65 books written by women, where they are authors or editors, and 12, where women are co-authors (Table 1.).

\section{Results and Discussions}

In this section we want to present main ideas of our research. It is all around impact of literature communication as a way of develop strategic communications in DoD. That's why we've chose military literature in Ukraine during the years of Russian aggression. We are convinced that it is literary sources written directly in times of military and political instability that can become a focal point for influencing society and correlating their behavior.

Literary sources from chaplains and professional writers and journalists are meaningful sources of constant action (training, advanced training, methodologies of understanding processes, unique factual generalizations, etc.) that create a mosaic of urgent problems, indicators, approaches, and are actually technological examples of cases and possible narratives for the future. Through experience in the ATO / JFO area, all participants, and especially the military, demonstrate in-depth motives for combat in the clash and authenticity of the call to bring peace in the form of a democratic civilization, not the ersatz peace of the neo-barbarians.

For the most part, it is advisable to consider the literary publications of the editorial offices of the military media and the press officers of the military units as a valid and reliable fact, and more accurately tested reference material for the ongoing mid-term and ongoing analysis of real sections of social parameters involved in the ATO / JFO area.

Particularly important are books as sources for research on and about Internally displaced person (IDPs). Through the prism of their reflections, one can indirectly, in the light of their personal characteristics, trace the formation of an entire region, including the Donetsk region and Luhansk region (which by the Soviet tradition is united under the provisional name Donbass), the influence on them by foreign agents, in particular, Russian armed forces. In these books, the emotional component is most prevalent than the fact that in today's dynamics and content-communication processes it is the basis for the post-truth, which, based on the sphere of feelings (most of all fear), creates the conditions for stimulating action and creating behavioral models that benefit certain «customers». information product. 


\subsection{Age of Post-truth or Propaganda}

In the analyzed sources of empirical information there are practically no direct statements that describe the concepts of «post-truth» and «fake» $(20 \%)$. This is direct evidence that contemporary reality is created through the mass media by describing emotionally and personally experienced situations close to one another. Most of them $(80 \%)$ are found in books published by the military media and in the stories of the press officers of the military units.

The vast majority of sources of information (70\%) analyzed contain terminology groups: «propaganda», «propagandists»; The Kremlin / Putin regime; «Post-truth»; «Misinformation», «fakes».

The study identified blocks of issues most commonly found in the sources studied (55\%): a communication issue between volunteer battalions and the regular army; issues of access to information in the ATO area and in the frontline; lack of official media / management / books / radio positions; the influence of the Russian mass media on the territory of Donbass; problems of communication with the local population, etc.

We illustrate our research with some quotations from literature's resources to support our opinion.

The word of the year 2017 was «fakenews» [3]. Collins English Dictionary defines fake news as «false, often sensational, information disseminated under the guise of news» [4]. Misinformation, in turn, is the deliberate spread of false / distorted information to distort reality. Generally speaking, we can refer to these concepts as a manipulative tool of «hybrid war», where the main component is information aggression and the creation of alternative reality.

«Hybrid war is playing both ways. As usual. Evening Prime Time. On the Internet: «betrayal», «naked, barefoot» and «patriots are poured into coppers» ... «[5].

"But if the network is traditionally dominated by the "yellow" and primitive fake, then the so-called "PutinTV" serves more "refined" dishes with different sauces. Unlike domestic TV channels, Russian ones not only do not differ in the variety of points of view, but also the reliability of information in the context of Ukrainian news. However, as the Third Reich propaganda minister Joseph Goebbels said, "the more monstrous a lie, the easier it is to believe in it." Channel One, Russia 1, Russia 24, NTV, and even the TV channel "Zvezda" of Russian Ministry of Defense. It is there that myths about "Bendery" and the eating of Russian babies are born, and it is they who are almost the most important anti-Ukrainian mouthpiece on Russian TV. Moreover, Russian propaganda has three categories of consumers: the Russians themselves, Ukraine and the rest of the world" [6].

In 2016 the Oxford Dictionary defined "post-truth" as the word of the year and gave it the following interpretation: "The word describes the circumstances in which appealing to emotions and personal beliefs is more important in forming public opinion than objective facts" [7]. Therefore, quotes from the above sources clearly demonstrate this tendency, where before the facts of significant publications speak, emotions will come to power.

"If terrorists fire (ed. - shelling of Ukrainian positions, most often, are clearly directed by Kremlin propagandists and specially filmed by Russian TV channels), Ukrainian troops and residential quarters of their own countrymen from the territory of the church yard - in a few days the Russian media will be sensed" "That it was the" junta "! Only by counting on the total illiteracy of the electorate, or by being convinced of all the effectiveness of its propaganda machine, could the Kremlin regime put into the heads of the Russian citizens the assent of the "junta". In the end, nothing new Russian propaganda invented: experts in special operations of information nature chose the method of point punches in the minds of their citizens, knowing perfectly where, actually, to beat" [8].

Since Ukraine's independence, Russia has formed the image of a "younger brother", continuing the policy of identifying Ukrainians as a nation with Russians in mass culture by imposing linguistic similarity, mentality, community of history, ethnographic origin, etc.

«We only mentioned three films, and how many were there! Movies, TV shows, talk shows, newspaper publications and more. And everyone has an alternation of ridicule («Hohli», «Fat») with direct accusations of everything and everything - pro-American power, the same fascists-bandera, fictitious thefts of gas from Ukraine, and dozens of other big and not so bad things. Everything, the image of the enemy in the person of the Ukrainian was created, the talented heirs of Goebbels propaganda of the new, Kremlin type tried for glory, which, accordingly, was immediately reflected in their accounts in foreign banks!» [9]. This quotation shows us feeding the feeling of underperformance, destroying national identity.

\subsection{Emotions as a War Tool}

Emotions are an essential part of media work. It involves both excitement, fun, exhilaration as well as tension, stress, grief, horror and even trauma. In journalism emotional labour is often strongly present in the work of foreign correspondents and exceptional and unexpected events, such as wars and disasters or in the work of journalists who cover delicate social issues (abuse, poverty) (Richards \& Rees 2011; Santos 2009; Hopper \& Huxford 2015). Research on media work and emotions has found that the management of emotions is an increasingly important part of work in a sector that has become highly competitive, precarious and uncertain [18]. 
Literature also has a vital emotional impact on its audience. Any element of the story world, the points of view, the language itself and the tone (or mood) participate in creating what we call emotion effects. These are the effects that literary texts trigger on authorial audiences [19].

Literature as a part of strategic communications has had a major impact on the development of society. It has shaped civilisations, changed political systems and exposed injustice. However, just as it has constructed societies, the writings and works of certain authors have degraded societies to their most primitive form. In other hand, literature confirms the real complexity of human experience [20].

Nowadays all of mass media, include literature, make up diversity of ways to influence on political and social processes. Studying the influence of Russian information campaigns, we came to the conclusion that literature acts as a field and a means of forming new realities. Russian information strategy works on the principle of advertising and demonstration technologies, which are based on emotions of fear, identification with the character, frequent repetitions, and mass distribution.

"There was also an understanding of what we had to deal with: these insightful and sincere lines were nothing more than another" product "of the Russian anti-Ukrainian information machine ... The experience of the Russian war on information warfare is lacking, because all its history is waged by Russia, and war is unjust" [10].

The notion of hybrid warfare in this context can be used not only to refer to warfare, but also to the feeling of war directly in the conflict zone and in peaceful territories, where the sense of war becomes a commonplace phenomenon, and Ukrainian heroes are lost to ordinary statistics. The thesis "we are all tired of the war" manipulated the media, creating an alternative reality and geographical distance between parts of Ukraine.

A special place in the system of communication and content security is held by the press officers whose task is to respond promptly and inform the commander and the unit. Thanks to press officers, a local press was revived in the Armed Forces, such as the most famous Der Hunt Zaitung, a humorous volunteer newspaper for fighters in the ATO / JFO area; the brigade newspapers of the 72 brigade "Eastern Front" on the initiative of the press secretary Elena Mokrenchuk, "The banner of victory" and "Honor and Will"; many military units issued warheads or other products.

"Some weird flags of some "Donetsk Republic". It seemed to me just a theater of the absurd. And there was no fear. For in vain they say: happiness in ignorance..." [11].

That's why Russian information aggressions are inherently aimed at "ignorance." This may be ignorance of the topic, language, thought leaders, etc. It is worth talking about the level of education of consumers of the information product. or vocational education, youth, monolinguals, etc.

The experts say that we have to fight using information. At the same time counteracting and responding to Putin's fakes is a software strategy that only legitimizes such insinuations in the information space. Contemporary communication and content security must be based on the creation of scripts and new formats to combat the creative and technological impetus. Since, artistically and technically, we do not yet have the capacity to confront this, our weapons are true.

From the sources analyzed, the problem arises of creating adequate information space in an environment where hostile communication expansion is prevalent. After all, the Russian invaders are fighting for the minds of the population, their information preferences and emotional intelligence, which are largely under the control of the social media, including the most widespread channels of information in the ATO area were social networks and radio.

\subsection{Danger of Lack of Information}

Thus, before the Ukrainian authorities started the ATO the problem of filling the information vacuum in the front and frontal area with a Ukrainian product. For example, government magazines, including the Government Courier, the Voice of Ukraine, the newspaper of the MOD "People's Army" and its special issue, were included in the anti-terrorist operation zone. Other media inquiries were covered by social media. And, according to researchers, notably David Patrickarakos in the book "War on 140 Characters", it was social media that was the first to report on the events in the ATO zone, and with its accessibility, closeness to people, speed and imagery gained more trust from the population than official publications.

Therefore, it is the modern mass media that are decisive in communication-content processes. Based on their analysis, it is advisable to develop the necessary techniques to help military personnel in the area of JFO: information hygiene, personal identification in social networks, their own Internet presentation, publicity, personal cases of private information about themselves and the environment in any digital dimensions, etc....

"One of the topics of interrogation is on social networks. "You wrote this here? Are these your beliefs?" Questioning is a psychological game. Will you defeat them with your "Yes" or will they ... Social networks in such cases is a very big evil ... " [12].

As noted, combat radio became almost one of the main channels of information through its broadcast 
network, which filled both the cognitive hunger of fighters and entertainment needs.

An important place among the communication channels was occupied by "sarafan radio" (in modern interpretation - word of mouth marketing or marketing of gossip), phone calls to home and so on. For example, information about humanitarian convoys in the territories controlled by the occupiers could only be obtained from social networks or from relatives who were watching television and radio broadcasts. Therefore, the soldiers felt the need for official printed information sources that would provide necessary and timely clarification.

For example, information about the direction from the Russian Federation to the Donetsk region or the Luhansk region of the so-called humanitarian mission over time became identified as the beginning of armed exacerbations, shelling of Ukrainian positions and the possible death of soldiers. On the other hand, this was important information for maintaining the life and health of the soldier, but due to the problem of external and internal communications, it was not properly assigned to the individual executor of the combat task.

"Despite the environment, the density of shelling in Lugansk was increasing ... From the news on our smartphones and calls home, when we were in range of the satellite network, we learned about some of the talks that were being prepared and about the hum-convoy" [13].

Along with the problem of information in the ATO / JFO area (where there is a small percentage of highquality press and Ukrainian radio that could broadcast accurate and objective information), there is a problem of INFORMATION NEEDS / LACKS in the area of general education, including art and literature. In our opinion, the creation of mini-libraries, mobile cinemas, touring artists answer several requests: the possibility of emotional unloading, strategic planning of possible life situations, raising the general education and linguistic culture, etc.

"... The agenda... Someone watched movies, someone read... A book wandered through the bin. Nietzsche "So said Zorathustra." She was taken in turn, but something she never left. Obviously, the environment did not inspire that granite of philosophical thought ..." [14].

Thus, the period of the counter-terrorism operation (April 6, 2014 - April 30, 2018) and the operations of the Joint Forces (April 30, 2018 - until now) showed the importance of timely and objective briefing of Ukrainian troops both in the area of combat and in the peace area. The problem of lack of information is reflected not only in the moral and psychological state of the soldiers, the ability to adequately threaten and make decisions, but also the ability to quickly respond creatively to the information aggression of the enemy. We emphasize on it because that can be the weakness of personnel.

\subsection{Is the Literature Ideology?}

Having considered the sources of literature, it is necessary to distinguish the concept of "ideology" as a manipulative installation with no choice. As the Donbas as a region has limited information space (the dominance of Russian-language literature, the media, the predominance of Russian in everyday life and at the level of official institutions), the Russian Federation therefore has a monopoly on information. In such closed systems, ideology can work, that is, forcing a favorable position to create a behavioral model. However, European practice operates on the concept of "value", which aims at shaping national identity and attachment to cognitive choice rather than suggestion. Thus, value choice can be explained and accepted / not accepted, but ideology remains a sphere of guidance from above, and more precisely, moral-psychological and mental pressure.

"How to counter armed people? Ideologically - partially. That is, Kramatorsk residents who listened to Russian propaganda explained that this was all a hoax, and nothing good could be brought to our land by our northern neighbor" [15].

Why are we losing the information war? This question sounds not only from the mouths of politicians, public figures, experts. This problem is widely raised in fiction, memoirs, and documentary fixations by fighter authors. Analysis of the sources of the study shows that in Ukraine there is generally no mechanism for systematic counteraction to hybrid aggression and information operations. The reason for this is the unspecified information policy of the state: both to the internal audience and to the international community. Therefore, first of all, we have identified and analyzed such concepts as "post-truth" and "hybrid war" as the realities of the new era and "misinformation" and "fake" as tools for achieving the goals of "post-truth" and "hybrid war".

\section{Conclusions}

The analyzed source confirmed that fake and post-truth are artificially created and manipulative-imitation technologies that Putinists use for hybrid warfare. By imposing the post-truth era on the international community, the Kremlin regime creates a reality where emotions are dominated by facts. Thus, Russia's information strategy is based solely on the needs of the lower order.

Since mass culture has penetrated all walks of life, one of the goals of our research work is to study public 
communication-content negatives, in particular in the mass media, to which we include fiction. The source of our study was prose works for the period 2014-2018, describing the armed aggression of Russia against Ukraine, written by direct participants in hostilities, volunteers, internally displaced persons (real refugees), public figures, journalists, writers.

According to the results of the study, it can be argued that $30 \%$ of the total number of sources corresponded to the most scientific inquiry. Particularly important for understanding public negatives were the concepts of «hybrid war», «post-truth», «fake», «misinformation», on which we focused our intelligence. In particular, the source database analyzed confirmed that fake and post-truth are artificially created and manipulative-imitation technologies that Putinists use to wage a hybrid war. By imposing the post-truth era on the international community, the Kremlin regime creates a reality where emotions are dominated by facts. Thus, Russia's information strategy is based solely on the needs of the lower order.

In the course of the study, a number of problems were identified: lack of diverse information directly in the ATO area, insufficient number of state-owned media, poor external and internal communication, lack of sufficient cultural enrichment of fighters as a way of psychological unloading.

The study showed that the Armed Forces of Ukraine need clear information on the state's policies and strategies; information and media structures should pay attention to in-depth study of the target audience and their needs for quality information and coverage of the official position of the state; ways of providing units, in particular in the area of $\mathrm{CAB}$, of printed matter (newspapers, magazines, books) should be determined; to provide explanatory work; to develop own scenario decisions for preventive actions on information aggression of the enemy; define tactical tasks for the press services in the units and more.

\section{Acknowledgements}

This work was performed within the framework of a research work on «The research of public-content negatives in the modern dynamics of different forms of hybrid aggression practices». The authors are grateful to the Military Institute of Taras Shevchenko National University of Kyiv for the opportunity to explore and demonstrate the importance of content, especially negative ones, as a new challenge to the country's information security.

\section{References}

1. Сидоренко С. Росія робить крок до холодної війни: про що говорили на Мюнхенській конференції. Available from: https://www.eurointegration.com.ua/articles/2017/02/20/7061906/

2. Post-Truth, Post-West, Post-Order? Available from: https://www.securityconference.de/publikationen/munichsecurity-report/munich-security-report-2017/

3. Fake news стало словом 2017 року. Available from: https://www.bbc.com/ukrainian/other-news-41844435

4. Fake News Definition and Meaning: Collins English Dictionary Available from: https://www.collinsdictionary. com/dictionary/english/fake-news

5. Голос війни. Історії ветеранів - Київ: ТОВ «Рема Прінт», 2017. - 223 pp., p. 188

6. Коли грянув грім. Під загальною редакцією Миколи Поплавського. - Вінниця: ДО МОУ “Крила України”, 2016. - 480 с. - (Художньо-документальне видання). - (1), р. 36

7. Post-truth Definition and Meaning: Oxford Dictionary. Available from: https://www.oxfordlearnersdictionaries. com/definition/english/post-truth

8. Коли грянув грім. Під загальною редакцією Миколи Поплавського. - Вінниця: ДО МОУ “Крила України”, 2016. - 480 с. - (Художньо-документальне видання). - (1), р. 63

9. Голос війни. Історії ветеранів - Київ: ТОВ «Рема Прінт», 2017. 223 рр., p. 61

10. 100 днів полону, або Позивний «911»/ Валерій Макеєв; худож-іл. С. Захаров; худож.-оформлювач Л.П. Вировець. - Харків: Фоліо, 2016. - 192 р.: іл., р. 109

11. Звіт за серпень'14 / Андрій Сова (Плохіш); худож.-оформлювач В.М. Карасик. - Харків: Фоліо, 2017. 156 р.: іл., р. $96-97$

12. Звіт за серпень'14 / Андрій Сова (Плохіш); худож.-оформлювач В.М. Карасик. - Харків: Фоліо, 2017. 156 р.: іл., р. 110

13. Коли грянув грім. Під загальною редакцією Миколи Поплавського. - Вінниця: ДО МОУ “Крила України”, 2016. 480 р. - (Художньо-документальне видання). - (2), с. 428

14. Біличенко О. Літературні комунікація як об’єкт загальної теорії соціальних комунікацій / О. Л. Біличенко. // Вісник ХДАК. 2015.. - 2015. - С. 26-33.

15. Різун В.В. До питання про соціальнокомунікаційний підхід у науці / Різун В.В. // Комунікація. - 2010. - о 1. - C. 35-36.

16. Hsieh, H.-F., \& Shannon, S. E. (2005). Three Approaches to Qualitative Content Analysis. Qualitative Health 
Research, 15(9), 1277-1288. https://doi.org/10.1177/1049732305276687

17. Kirsty Williamson, Lisa M. Given, Paul Scifleet, Chapter 19 - Qualitative data analysis, Editor(s): Kirsty Williamson, Graeme Johanson, Research Methods (Second Edition), Chandos Publishing, 2018, Pages 453-476

18. Nikunen, K. (2019) Media, emotions and affect. In Curran, J. and Hesmondhalgh, D. (eds.) Media and Society, 6th ed. London: Bloomsbury, pp. 323-340.

19. Rossi, Riikka (Participant). Literature and emotions: creating emotion effects and affecting readers [Електронний pecypc] / Rossi, Riikka (Participant), Nykänen, Elise (Participant), Hollsten, Anna (Participant) // University of Helsinki. - 2010. Available from: https://researchportal.helsinki.fi/en/projects/literature-and-emotions-creatingemotion-effects-and-affecting-re.

20. Manal Ismail. Literature is the mirror of society [Електронний pecypc] / Manal Ismail, Staff Reporter // General Assembly. - 2008. Available from: https://gulfnews.com/general/literature-is-the-mirror-of-society-1.86134. 